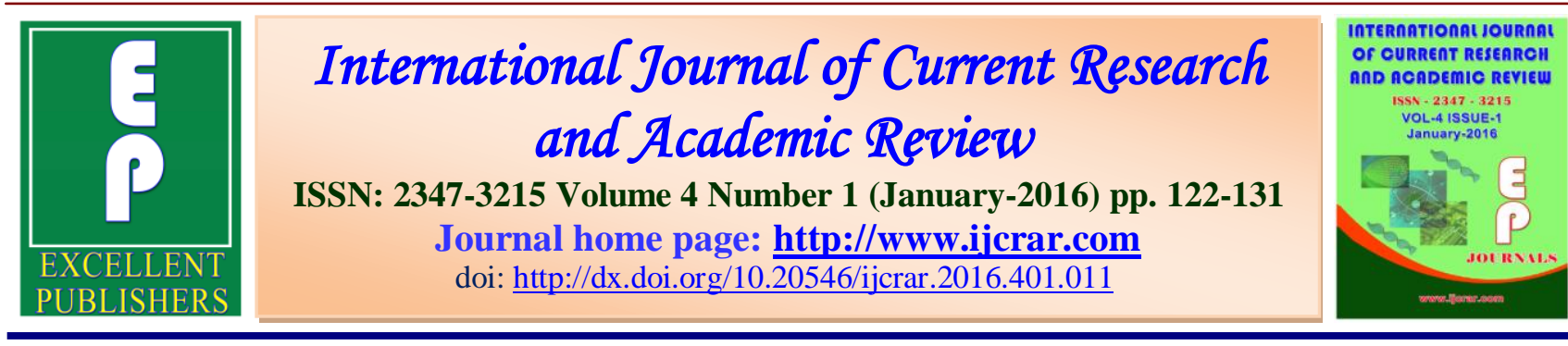

\title{
Optimizing Sowing Time and Row Spacing for Summer Sesame Growing in Semi-arid Environments of India
}

\section{Bachubhai A. Monpara* and Devshibhai R. Vaghasia}

Agricultural Research Station, Junagadh Agricultural University, Amreli- 365601, Gujarat, India

*Corresponding author

\section{KEYWORDS}

Sesamum indicum,

Yield and yield attributes, Interaction effects, Growing degree days,

Economics

\section{A B S T R A C T}

Sesame is grown predominantly in Kharif with low productivity. To increase productivity by minimizing environmental effects, the better management option is to grow it in summer. Hence, to decide appropriate date of sowing and row spacing, an experiment was conducted with three sowing dates $\left(\mathrm{D}_{1}=1^{\text {st }}\right.$ February, $\mathrm{D}_{2}=15^{\text {th }}$ February and $\mathrm{D}_{3}=1^{\text {st }}$ March) and three row spacings $\left(S_{1}=\right.$ Broadcasting, $S_{2}=30 \times 10 \mathrm{~cm}$ and $\left.S_{3}=45 \times 10 \mathrm{~cm}\right)$ for three years. Consistent results were obtained over the years. Reduction in vegetative duration (VD) and reproductive duration (RD) was observed due to delay sowing. Date of sowing also affected the growing degree days (GDD) during VD and RD. Decreased GDD for RD with delay sowing was related to reduction in length of RD. Early or late sowing than $15^{\text {th }}$ February adversely affected the seed yield. Average yield advantage of $15^{\text {th }}$ February sown crop was $151.7 \%$ and $10.1 \%$ higher over early and late sown crop, respectively. Yield attributing traits also revealed maximum expression in $15^{\text {th }}$ February sown crop. Spacing treatments differed significantly for seed yield. The highest seed yield was gained at $30 \times 10 \mathrm{~cm}$ spacing to the tune of $13.6 \%$ and $15.4 \%$ higher over broadcasting and $45 \times 10 \mathrm{~cm}$ spacing, respectively. Sowing of sesame on $15^{\text {th }}$ February at spacing of $30 \times 10 \mathrm{~cm}$ is recommended for sustainable cultivation in semi-arid environments with high economic benefit.

\section{Introduction}

Sesame (Sesamum indicum L.) has a longstanding history of cultivation and a wide range of usages. It is the first oil seed plant cultivated in the world and has a great importance in Indian culture as well. It is important crop for nutritional security, sustainable development and poverty alleviation of small and marginal farmers. Sesame is quality edible oil, food, biomedicine and health care, all in one. Sesame has remarkable antioxidant function because of lignans and tocopherol present in 
it. The seeds are rich in quality proteins and essential amino acids especially methionine that is why it is considered as rejuvenative and anti aging. In the recent past, the international demand and market for sesame has witnessed substantial growth.

India is the leading country worldwide so far area and production of sesame, however, the highest yield $(1333 \mathrm{~kg} / \mathrm{ha})$ is harvested in Egypt (FAO, 2013). In India, very low productivity of sesame is mainly due to rainfall dependent growing conditions with low input management. Higher productivity can be realized if it is grown in summer. Summer season provides favourable weather parameters such as photoperiod and temperature and unfavourable weather condition with respect to diseases and insect pests attack. Therefore, concerted efforts are needed to insist farmers for summer cultivation where irrigation facility is available. A gradual shift of the sesame crop from kharif to summer is desirable.

Sesame is a short-day plant and generally requires fairly hot conditions $\left(25-27^{0} \mathrm{C}\right)$ for its optimum growth and yield. Temperatures below $15^{\circ} \mathrm{C}$ and above $40^{\circ} \mathrm{C}$ at flowering may lead to premature flower drop or production of sterile pollen (Ranganatha, 2010). Growing degree days (GDD) is a tool to find out the relationship between mean air temperature, plant growth and maturity (Qiao-yun et al., 2012). The GDD indicates the thermal requirement of a particular crop (Singh et al., 2014). The sensitivity of rainfed sesame to the changes in temperature is well known (Meena and Rao, 2013) but not quantified under summer sowing conditions.

Among the factors necessary for successful production of crop, time of sowing can have a major effect on final size of plants and the yield (Langham, 2007). Yield decreases progressively with the delay in planting from optimum time of sowing (Alam Sarkar, 2007).

Proper method of sowing is another important factor that determines the proper plant population in the field. Broadcasting is the common practice for summer sowing in the region. It is well known that broadcasting method always resulted in uneven plant spacing in the field. Even plant stands have mostly yield advantage over uneven plant spacing (Caliskan, 2004). Reduction in row spacing increases the plant height but decreases capsule numbers per plant (Rahnama and Bakhshandeh, 2006).

Suitable environmental condition and row spacing between plants both are necessary for optimum plant growth and crop yield. The response of sesame to sowing dates showed that yield of summer production decreases with delay sowing beyond first week of March (Patel et al., 2010) and early sowing before 12th February (Patil et al., 1992). Roy et al. (2009) obtained higher yield of sesame when row to row distance was $30 \mathrm{~cm}$ and it was decreased at distance of $45 \mathrm{~cm}$. On the other hand, Caliskan et al. (2004) reported positive effects of row planting over broadcasting planting on seed yield and its components in sesame. In fact, it is necessary to understand the interaction of planting geometry with weather because both these factors plays important role in plant growth. There is, however, a dearth of information on suitability of both these factors for summer cultivation of sesame. This study was, therefore, carried out to obtain information necessary to develop effective strategies for summer sesame production under semi-arid environments.

\section{Materials and Methods}

The study area of Amreli district, the Agricultural Research Station, Amreli, is located in the Northern agro-climatic zone 
of Gujarat in the western part of India. The geographical position of the area lies between $21^{\circ} 35^{\prime} 79^{\prime \prime} \mathrm{N}$ and $71^{\circ} 12^{\prime} 82^{\prime \prime} \mathrm{E}$ with the elevation of $130 \mathrm{~m}$ above mean sea level. The study was performed to evaluate the effect of sowing dates and row spacings on growth and yield of sesame under summer condition during the period from February to May of 2009, 2011 and 2012. In 2010 experiment was not conducted due to shortage of water. Multi-capsular cultivar G. Til 2 of indeterminate type with few branch, medium maturity and sparse hairiness on stem and capsules was used for experimentation. A composite soil sample was collected at random in the entire plot before the experiment to determine the chemical property of the experimental site in each year (Table 1). The soil of the experimental site was a medium black type. The soil was also slightly alkaline with low in available $\mathrm{P}$, medium in available $\mathrm{N}$ and organic carbon, and high in available $\mathrm{K}$.

As sowing date and row spacing both factors requires big plot size, the experiment was laid out in strip plot design with four replications. Sowing dates were relegated to horizontal strip plots and row spacings to vertical strip plots. Each plot size was of $5.0 \times 2.7 \mathrm{~m}$. There were three sowing dates $\left(D_{1}=1^{\text {st }}\right.$ February, $D_{2}=15^{\text {th }}$ February and $\mathrm{D}_{3}=1^{\text {st }}$ March $)$ and three row spacings $\left(\mathrm{S}_{1}=\right.$ Broadcasting, $\mathrm{S}_{2}=30 \times 10 \mathrm{~cm}$ and $\mathrm{S}_{3}=$ $45 \times 10 \mathrm{~cm})$. Sowing was done at recommended seed rate of $3.0 \mathrm{~kg}$ per hectare in all treatments. Seeds were broadcasted in broadcasting treatment and hand drill in row sowing plots. In row spacing plots, plants were thinned at 20 days after sowing keeping plant to plant distance of $10 \mathrm{~cm}$. Seed was treated with Thirum fungicide $(3.0 \mathrm{~g} / \mathrm{Kg}$ seeds) before sowing to check soil/seed born diseases. The recommended dose of fertilizers $(50 \mathrm{~kg} \mathrm{~N}$ $\mathrm{ha}^{-1}$, and $25 \mathrm{~kg} \mathrm{P}_{2} \mathrm{O}_{5} \mathrm{ha}^{-1}$ ) was applied to plot by broadcast or hand drill as per the treatment. The nitrogen was applied in two split doses, one-half $\mathrm{N}$ in the form of Ammonium Sulphate and total quantity of $\mathrm{P}$ in the form of Diammonium Phosphate was given before sowing and remaining $1 / 2 \mathrm{~N}$ was applied in the form of Urea at 25 days after sowing following irrigation. Crop was adequately irrigated with flood irrigations. A total of nine, eight and seven irrigations were required during growth period of the crop sown on $1{ }^{\text {st }}$ February, $15^{\text {th }}$ February and $1^{\text {st }}$ March in all the years, respectively. Crop care except those under study was uniformly carried out for all treatments during the experimentation.

Five plants were taken randomly from the central part of each net plot before harvesting to measure the characters. Data on plant height $(\mathrm{cm})$, capsules plant ${ }^{-1}$ and primary branches plant ${ }^{-1}$ were collected on plant basis at harvest. Plant height was measured in $\mathrm{cm}$ from ground level to the tip of main shoot. Final plant stand $\mathrm{ha}^{-1}$, days to $50 \%$ flowering, days to maturity, 1000- seed weight (g) and seed yield $\mathrm{kg} \mathrm{ha}^{-1}$ were recorded on net plot basis. The crop was harvested plot-wise at full maturity (when leaves start to turn yellow and bottom capsules became lemon yellow) according to treatments separately from net area of $4.2 \times 1.8 \mathrm{~m}$ (i.e., $4.2 \mathrm{~m}$ length, $1.8 \mathrm{~m}$ width). The harvested sample crop of each plot was bundled separately, tagged and placed on a threshing floor. The bundles were thoroughly dried in bright sunshine until fully dried, then threshed and weighed. The vegetative duration (VD) was measured as duration from days after sowing to days to $50 \%$ flowering and reproductive duration (RD) was computed as duration from days to $50 \%$ flowering to days to physiological maturity (Olowe, 2007). Data on maximum and minimum temperatures during the crop growth period were collected from our meteorological observatory about $200 \mathrm{~m}$ away from the experimental site (Fig. 1). 
The accumulated Growing Degree Day (GDD) from sowing to flowering and flowering to maturity was computed as:

$\mathrm{GDD}=\Sigma(\mathrm{T} \max +\mathrm{T} \min ) / 2-\mathrm{Tb}$

Where, $\Sigma$ is summation, Tmax and Tmin are the daily maximum and minimum air temperature, respectively. The $\mathrm{Tb}$ is the base temperature below which crop growth and development ceases. In case of sesame crop, the $\mathrm{Tb}$ considered in present study is $10^{\circ} \mathrm{C}$.

Data recorded on yield and yield attributes were subjected to analysis of variance (ANOVA, $\mathrm{p} \leq 0.05$ ) according to strip plot design suggested by Hoshmand (2006). Treatment means were compared by calculating critical difference (CD) at $\mathrm{P} \leq 0.05$ probability level. The data were analyzed on SAS and Excel. Figures were drawn using MS excel 2007 programme. The economics of each treatment combination was calculated as per the prevailing prices of inputs and outputs.

\section{Results and Discussion}

\section{Weather Conditions}

The mean values of minimum and maximum temperature as well as relative humidity recorded during crop duration of sesame for summer 2009, 2011 and 2012 (Fig. 1) indicated that temperature was cooler/lower, especially during establishment/ early vegetative growth and remained constantly warmer during reproductive duration in all the years. In general, the late cropping season of 2009 was slightly warmer with lower relative humidity than that of 2011 and 2012. The vegetative duration (VD) ranged from 38 to 43 days and reproductive duration (RD) varied from 36 to 72 days over the years (Table 2). The VD and the RD reduced with delay sowing.
Accumulated growing degree days (GDD) calculated for vegetative duration (VD), i.e., from sowing to $50 \%$ flowering and reproductive duration (RD), i.e., from $50 \%$ flowering to physiological maturity as related to three sowing dates (Table 2) indicated that delay sowing was associated with increasing GDD for VD and decreasing GDD for RD.

\section{Effect of Sowing Date and Row Spacing on Yield and Yield Attributes}

Pooled analysis over three years for seed yield and its attributing traits (Table 3) revealed significant differences among sowing dates and row spacings for all the traits under consideration, except plant height and capsules plant ${ }^{-1}$ with sowing dates. Seed yield and plant stand $\mathrm{ha}^{-1}$ was significantly higher at $\mathrm{D}_{2}$ (15th February) than $\mathrm{D}_{1}\left(1^{\text {st }}\right.$ February) and $\mathrm{D}_{3}\left(1^{\text {st }}\right.$ March $)$. Days to $50 \%$ flowering and maturity decreased with delay sowing. Seed size (1000-seed weight) was the highest at $\mathrm{D}_{2}$ and was reduced either on early or late sowing. Row spacing of $\mathrm{S}_{2}$ recorded significantly the highest seed yield $(1,050 \mathrm{~kg}$ $\mathrm{ha}^{-1}$ ). Plant stand $\mathrm{ha}^{-1}$ was the highest in broadcasting $\left(\mathrm{S}_{1}\right)$ and reduced significantly with wider spacing. Days to 50\% flowering and maturity were also affected by row spacings. Wider the spacing, delay was to occur $50 \%$ flowering and maturity. Also, plant stature was shorter in broadcasting $\left(\mathrm{S}_{1}\right)$ and became taller with wider spacing. Capsules plant ${ }^{-1}$, branches plant ${ }^{-1}$ and 1000seed weight were significantly the highest at the $S_{2}(30 \times 10 \mathrm{~cm})$ spacing.

The pooled data over three years (Table 3) showed that interaction between sowing dates and row spacings (DxS) was significant for seed yield, plant stand, days to maturity, branches plant ${ }^{-1}$ and 1000-seed weight. Interaction effect of years with dates of sowing (YxD) and years with row 
spacings (YxS) were significant in almost all the characters studied. Thus, indicates that there was a greater influence of summer environments on crop growth and development.

Two way data (Table 4) indicated that significantly higher seed yield was achieved at $\mathrm{D}_{2}$ with $\mathrm{S}_{2}$. Plant stand was significantly lower in $D_{1}$ than $D_{2}$ and $D_{3}$ in all the row spacing. The crop matured within 90 days when sown on $\mathrm{D}_{3}$ with $\mathrm{S}_{1}$ but it took more days to mature on early sowing and wider spacings. Similar trend was also observed for branches plant ${ }^{-1}$. The1000-seed weight was significantly the highest $(3.06 \mathrm{~g})$ at $\mathrm{D}_{2}$ with $S_{2}$ and significantly the lowest $(2.61 \mathrm{~g})$ at $\mathrm{D}_{1}$ with $\mathrm{S}_{1}$.

\section{Economics}

Economics of different treatment was worked out on the basis of average seed yield over three years for each treatment combination of sowing dates and row spacings (Table 5). Differences in cost of cultivation for various treatments were due to difference in number of irrigation required to each date of sowing; one less irrigation was required to each late sowing date. The treatment $D_{2} S_{2}$ (Sowing at $15^{\text {th }}$ February and spacing at $30 \times 10 \mathrm{~cm})$ recorded the highest net return ((INR 65,980 $\left.\mathrm{ha}^{-1}\right)$ and CBR (1:3.30). The treatment $\mathrm{D}_{1} \mathrm{~S}_{3}$ (Sowing at $1^{\text {st }}$ February and spacing at $45 \mathrm{x}$ $10 \mathrm{~cm}$ ) gave the lowest net return ((INR 6,660 $\left.\mathrm{ha}^{-1}\right)$ and CBR (1:0.32).

Sesame is generally a warm region plant. The temperatures found to adversely affect the growth and development of summer sesame. Falling of initial minimum temperature below $15^{\circ} \mathrm{C}$ inhibits sesame seed to germinate (Ranganatha, 2010). In our study also initial minimum temperature at early sowing date ( $1^{\text {st }}$ February) was below $15^{\circ} \mathrm{C}$ in all the years (Fig. 1) which inhibited the germination. This was reflected by significantly lower plant population of the crop sown on $1^{\text {st }}$ February (Table 3). Changes in maximum and minimum temperature due to different date of sowing affected the length of VD and RD phenophases(Table 2). Delay sowing decreased both VD and RD, however, the effect was more pronounced on RD than VD. Langham (2007) opined that flowering stops earlier in late sown compared to early sown sesame.

Table.1 Physico-chemical Properties of the Experimental Sites

\begin{tabular}{ccccc}
\hline Sr.No & Particular & 2009 & 2011 & 2012 \\
\hline 1 & $\mathrm{pH}$ & 7.88 & 7.00 & 7.80 \\
2 & EC $\left(\mathrm{dSm}{ }^{-1}\right)$ & 0.21 & 0.23 & 0.24 \\
3 & Organic Carbon $(\%)$ & 0.57 & 0.55 & 0.58 \\
4 & Available N $\left(\mathrm{kg} \mathrm{ha}^{-1}\right)$ & 180 & 190 & 193 \\
5 & Available P $\left(\mathrm{kg} \mathrm{ha}^{-1}\right)$ & 20.50 & 25.00 & 23.50 \\
6 & Available K $\left(\mathrm{kg} \mathrm{ha}^{-1}\right)$ & 403 & 325 & 350 \\
7 & Texture & Medium & Medium & Medium \\
& & black & black & black \\
\hline
\end{tabular}


Int.J.Curr.Res.Aca.Rev.2016; 4(1): 122-131

Table.2 Growing Degree Days (0C- day) Requirement for Vegetative and Reproductive Phenophases of Sesame Grown at three Dates of Sowing

\begin{tabular}{ccccccc}
\hline Sowing date & \multicolumn{3}{c}{ VD } & \multicolumn{3}{c}{ RD } \\
\cline { 2 - 7 } & 2009 & 2011 & 2012 & 2009 & 2011 & 2012 \\
\hline $\mathrm{D}_{1}-1^{\text {st }}$ February & $665(43)$ & $608(43)$ & $539(42)$ & $1144(53)$ & $\begin{array}{c}1500(70 \\
)\end{array}$ & $1545(72)$ \\
$\mathrm{D}_{2}-15^{\text {th }}$ February & $731(41)$ & $648(41)$ & $623(41)$ & $1026(45)$ & $1344(60$ & $1456(65)$ \\
$\mathrm{D}_{3}-1^{\text {st }}$ March & $784(40)$ & $725(40)$ & $681(38)$ & $842(36)$ & $1325(57$ & $1376(61)$ \\
\hline
\end{tabular}

$\mathrm{D}=$ Date of sowing; $\mathrm{VD}=$ Vegetative duration; $\mathrm{RD}=$ Reproductive duration. Figure in parenthesis indicates duration of respective phenophase

Table.3 Pooled Analysis of Seed Yield and its Attributing Traits

\begin{tabular}{|c|c|c|c|c|c|c|c|c|}
\hline Treatment & $\begin{array}{c}\text { Seed } \\
\text { yield } \\
\mathrm{kg} \mathrm{ha}^{-1}\end{array}$ & $\begin{array}{c}\text { Plant } \\
\text { stand } \\
\mathrm{ha}^{-1}\end{array}$ & $\begin{array}{c}\text { Days to } \\
50 \% \\
\text { flowerin } \\
\mathrm{g}\end{array}$ & $\begin{array}{l}\text { Days to } \\
\text { maturity }\end{array}$ & $\begin{array}{l}\text { Plant } \\
\text { heigh } \\
\mathrm{t}(\mathrm{cm})\end{array}$ & $\begin{array}{l}\text { Capsules } \\
\text { plant }^{-1}\end{array}$ & $\begin{array}{l}\text { Branches } \\
\text { plant }^{-1}\end{array}$ & $\begin{array}{c}1000 \\
\text { seed } \\
\text { weight }(\mathrm{g})\end{array}$ \\
\hline \multicolumn{9}{|l|}{ Date of sowing (D) } \\
\hline $\begin{array}{l}\mathrm{D}_{1}-1^{\mathrm{st}} \\
\text { February }\end{array}$ & 497 & 90094 & 42.67 & 107.78 & 58.76 & 48.95 & 1.53 & 2.74 \\
\hline $\begin{array}{l}\qquad \mathrm{D}_{2-15^{\mathrm{th}}} \\
\text { February }\end{array}$ & 1251 & 275279 & 38.75 & 97.56 & 58.73 & 46.75 & 1.61 & 2.98 \\
\hline $\mathrm{D}_{3}-1^{\mathrm{st}}$ March & 1136 & 272046 & 37.78 & 90.47 & 58.71 & 43.29 & 1.32 & 2.87 \\
\hline S. Em \pm & 21.29 & 3763 & 0.15 & 0.21 & 0.79 & 1.80 & 0.05 & 0.02 \\
\hline $\mathrm{CD}(\mathrm{P} \leq 0.05)$ & 63.26 & 11181 & 0.43 & 0.64 & NS & NS & 0.14 & 0.06 \\
\hline $\mathrm{C} \mathrm{V}(\%)$ & 13.29 & 10.63 & 2.21 & 1.30 & 8.05 & 23.34 & 19.22 & 4.15 \\
\hline \multicolumn{9}{|l|}{ Row spacing (S) } \\
\hline $\begin{array}{l}\quad \mathrm{S}_{1} \text {-Broad } \\
\text { casting }\end{array}$ & 924 & 236258 & 39.61 & 97.00 & 57.21 & 43.43 & 1.22 & 2.81 \\
\hline $\mathrm{S}_{2}-30 \times 10 \mathrm{~cm}$ & 1050 & 219980 & 39.56 & 99.00 & 58.43 & 49.61 & 1.64 & 2.91 \\
\hline $\mathrm{S}_{3}-45 \times 10 \mathrm{~cm}$ & 910 & 181180 & 40.03 & 99.81 & 60.56 & 45.96 & 1.61 & 2.87 \\
\hline S. Em \pm & 18.83 & 6274 & 0.12 & 0.23 & 0.89 & 1.40 & 0.06 & 0.02 \\
\hline $\mathrm{CD}(\mathrm{P} \leq 0.05)$ & 55.96 & 18641 & 0.35 & 0.68 & 2.64 & 4.16 & 0.18 & 0.05 \\
\hline C V $(\%)$ & 11.75 & 17.72 & 1.80 & 1.40 & 9.09 & 18.12 & 24.92 & 3.49 \\
\hline \multicolumn{9}{|l|}{ Interaction } \\
\hline$(\mathrm{D} \times \mathrm{S})$ & $*$ & $*$ & NS & $*$ & NS & NS & $*$ & $*$ \\
\hline$(\mathbf{Y} \times \mathbf{D})$ & $*$ & $*$ & $*$ & $*$ & $*$ & $*$ & $*$ & $*$ \\
\hline$(\mathbf{Y} \times \mathbf{S})$ & $*$ & $*$ & $*$ & $*$ & NS & NS & $*$ & NS \\
\hline$(\mathbf{Y} \times \mathbf{D} \times \mathbf{S})$ & NS & $*$ & NS & $*$ & NS & NS & NS & NS \\
\hline
\end{tabular}

*= Significant at $\mathrm{P} \leq 0.05$ level; $\mathrm{NS}=$ non-significant 
Int.J.Curr.Res.Aca.Rev.2016; 4(1): 122-131

Table.4 Interaction Effect of Dates of Sowing and Row Spacings on Yield and Yield Attributing Traits (Pooled over three years)

\begin{tabular}{|c|c|c|c|}
\hline \multirow{2}{*}{$\begin{array}{c}\text { Trait/Date of } \\
\text { sowing }\end{array}$} & \multicolumn{3}{|c|}{ Row spacing } \\
\hline & $\mathrm{S}_{1}$ & $\mathrm{~S}_{2}$ & $\mathrm{~S}_{3}$ \\
\hline \multicolumn{4}{|l|}{ Seed yield, kgha $^{-1}$} \\
\hline $\mathrm{D}_{1}$ & 516 & 514 & 461 \\
\hline $\mathrm{D}_{2}$ & 1159 & 1433 & 1162 \\
\hline $\mathrm{D}_{3}$ & 1097 & 1202 & 1107 \\
\hline & S. Em. $\pm=29.68$ & \multicolumn{2}{|c|}{$\mathrm{CD}(\mathrm{P} \leq 0.05)=85.19$} \\
\hline \multicolumn{4}{|l|}{ Plant stand $\mathrm{ha}^{-1}$} \\
\hline $\mathrm{D}_{1}$ & 93364 & 90388 & 86530 \\
\hline $\mathrm{D}_{2}$ & 314264 & 284612 & 226962 \\
\hline $\mathrm{D}_{3}$ & 301146 & 284943 & 230049 \\
\hline & S. Em. $\pm=5550$ & \multicolumn{2}{|c|}{$\mathrm{CD}(\mathrm{P} \leq 0.05)=15931$} \\
\hline \multicolumn{4}{|l|}{ Days to maturity } \\
\hline $\mathrm{D}_{1}$ & 106 & 108 & 110 \\
\hline $\mathrm{D}_{2}$ & 95 & 98 & 99 \\
\hline $\mathrm{D}_{3}$ & 90 & 91 & 91 \\
\hline & S. Em. $\pm=0.31$ & \multicolumn{2}{|c|}{$\mathrm{CD}(\mathrm{P} \leq 0.05)=0.89$} \\
\hline \multicolumn{4}{|l|}{ Branches plant $^{-1}$} \\
\hline $\mathrm{D}_{1}$ & 1.38 & 1.55 & 1.67 \\
\hline $\mathrm{D}_{2}$ & 1.20 & 2.03 & 1.61 \\
\hline $\mathrm{D}_{3}$ & 1.07 & 1.35 & 1.55 \\
\hline & S. Em. $\pm=0.09$ & \multicolumn{2}{|c|}{$\mathrm{CD}(\mathrm{P} \leq 0.05)=0.27$} \\
\hline \multicolumn{4}{|c|}{1000 seed weight $(g)$} \\
\hline $\mathrm{D}_{1}$ & 2.61 & 2.79 & 2.83 \\
\hline $\mathrm{D}_{2}$ & 2.90 & 3.06 & 2.96 \\
\hline $\mathrm{D}_{3}$ & 2.90 & 2.88 & 2.82 \\
\hline & S. Em $\pm=0.03$ & \multicolumn{2}{|c|}{$\mathrm{CD}(\mathrm{P} \leq 0.05)=0.09$} \\
\hline
\end{tabular}

$\mathrm{D}=$ Date of sowing and $\mathrm{S}=$ Row spacing as details in Table 3

Table.5 Net Return and Cost Benefit Ratio for Different Combination of Dates of Sowing and Row Spacings in Summer Sesame (Pooled over three years)

\begin{tabular}{|c|c|c|c|c|c|}
\hline $\begin{array}{l}\text { Treatment } \\
\text { combination }\end{array}$ & $\begin{array}{l}\text { Seed yield } \\
\left(\mathrm{kg} \mathrm{ha}^{-1}\right)\end{array}$ & $\begin{array}{c}\text { Gross } \\
\text { income } \\
\left(\text { INR ha }^{-1}\right)\end{array}$ & $\begin{array}{l}\text { Cost of } \\
\text { cultivation } \\
\left(\mathrm{INR}_{\text {ha }}{ }^{-1}\right) \#\end{array}$ & $\begin{array}{l}\text { Net return } \\
\left(\text { INR ha }^{-1}\right)\end{array}$ & $\begin{array}{l}\text { Cost Benefit } \\
\text { ratio }\end{array}$ \\
\hline $\mathrm{D}_{1} \mathrm{~S}_{1}$ & 516 & 30960 & 21,000 & 9960 & $1: 0.47$ \\
\hline $\mathrm{D}_{1} \mathrm{~S}_{2}$ & 514 & 30840 & 21,000 & 9840 & $1: 0.47$ \\
\hline$D_{1} S_{3}$ & 461 & 27660 & 21,000 & 6660 & $1: 0.32$ \\
\hline $\mathrm{D}_{2} \mathrm{~S}_{1}$ & 1159 & 69540 & 20,000 & 49540 & $1: 2.48$ \\
\hline $\mathrm{D}_{2} \mathrm{~S}_{2}$ & 1433 & 85980 & 20,000 & 65980 & $1: 3.30$ \\
\hline $\mathrm{D}_{2} \mathrm{~S}_{3}$ & 1162 & 69720 & 20,000 & 49720 & $1: 2.49$ \\
\hline $\mathrm{D}_{3} \mathrm{~S}_{1}$ & 1097 & 65820 & 19,000 & 46820 & $1: 2.46$ \\
\hline $\mathrm{D}_{3} \mathrm{~S}_{2}$ & 1202 & 72120 & 19,000 & 53120 & $1: 2.80$ \\
\hline $\mathrm{D}_{3} \mathrm{~S}_{3}$ & 1107 & 66420 & 19,000 & 47420 & $1: 2.50$ \\
\hline
\end{tabular}

\# Cost of cultivation differs due to difference in number of irrigation $\left(D_{1}=9\right.$ irrigations; $D_{2}=8$ irrigations and $D_{3}=7$ irrigations)

$\mathrm{D}=$ Date of sowing and $\mathrm{S}=$ Row spacing as details in Table 3.

Market price: Sesame seed= INR 60/- $\mathrm{kg}^{-1}$ 
Fig.1 Temperature and Relative Humidity from Sowing to Harvesting of Summer Sesame Grown at Three Different Dates of 2009 (A), 2011 (B) and 2012 (C)
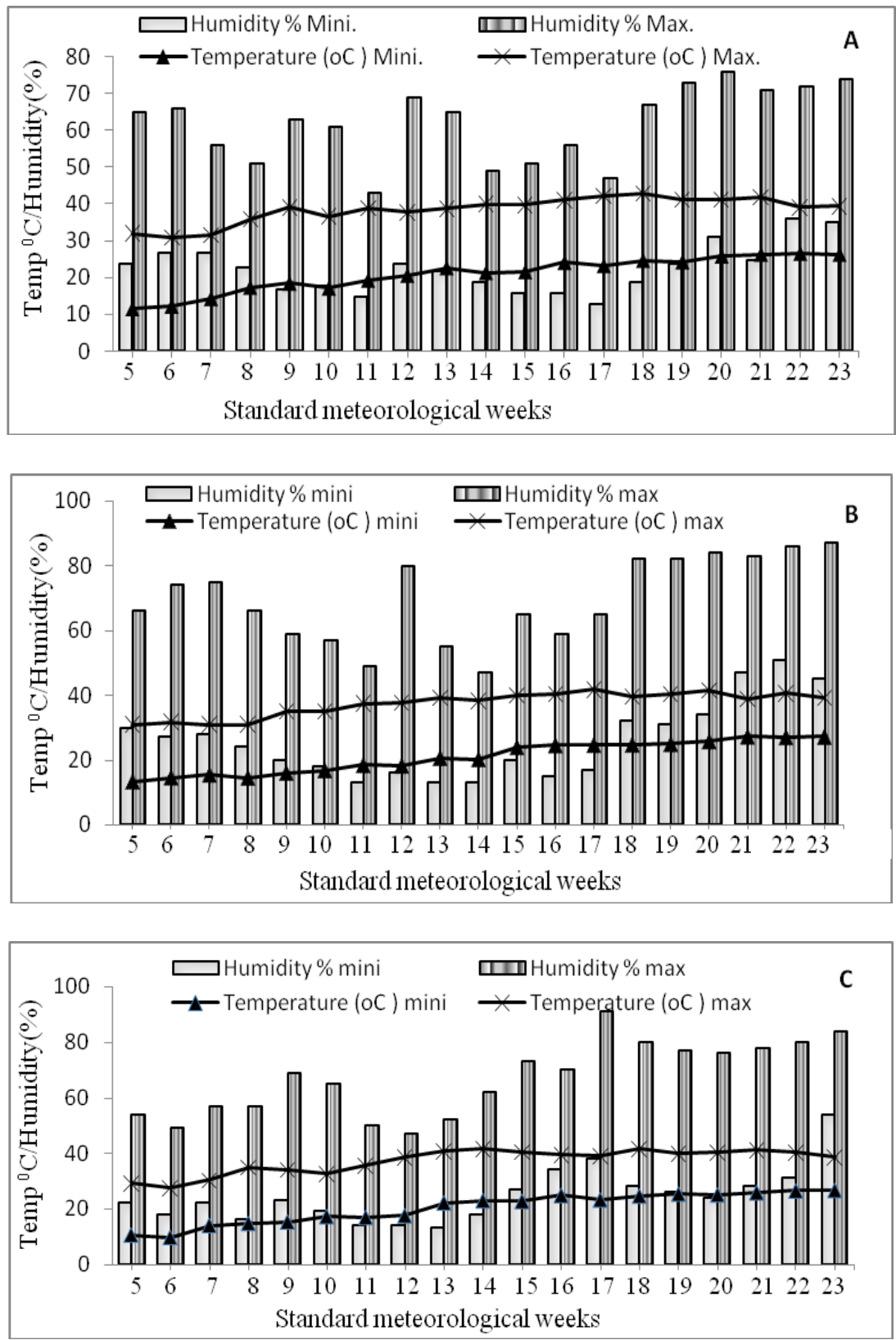

Days to $50 \%$ flowering and maturity were continuously decreased with delayed sowing; however, more pronounced effect was observed for days to maturity than days to $50 \%$ flowering. Ogbonna and UmarShaaba (2011) suggested that delayed flowering and maturity in the early planted crops possibly because of prolonged vegetative growth enhanced by favourable condition for growth which probably delayed reproductive development but the high temperature at later stage could short down the reproductive phases (Langham, 2007).

The row spacing of $30 \times 10 \mathrm{~cm}$ was found to be optimum with significantly the highest seed yield, capsules plant ${ }^{-1}$, branches plant ${ }^{-1}$ 
and 1000-seed weight (Table 3). At this spacing, the yield was realized higher to the tune of $13.6 \%$ and $15.4 \%$ over broadcasting and $45 \times 10 \mathrm{~cm}$ spacing treatments, respectively. Increasing in days to $50 \%$ flowering, days to maturity and plant height at wider spacing $(45 \times 10 \mathrm{~cm})$ can be attributed to gaining of sufficient sunlight, water and nutrition from soil and less inter plant competition, which can influence healthy yield of plant (Caliskan, 2004). Higher seed yield at $30 \times 10 \mathrm{~cm}$ most probably because of plants had more capsules and branches and higher 1000-seed weight (Table 3). These characters are responsible to contribute major share toward seed yield in sesame (Monpara et al., 2008).

Major advantage of the design used in the present study is estimation of interaction with greater precision than the main effects. Different row spacings responded differently to sowing dates. Seed yield (1433 kg ha ${ }^{-1}$ ), branches plant $^{-1}$ (2.03) and 1000-seed weight (3.06) were recorded significantly the highest when crop was sown on $15^{\text {th }}$ February with $30 \times 10 \mathrm{~cm}$ spacing (Table 4). Higher seed yield and 1000-seed weight as well as more branches plant ${ }^{-1}$ in this sowing date and spacing is the fact that the crop enjoyed optimum environmental conditions with less competition between plants for light interception thereby increasing rate of assimilation and seed mass production. In case of days to maturity, a trend of delay maturity on early sowing and at wider spacing was noted. Late maturity in early sown sesame was reported by Olowe (2007). Significant interaction effect of years with dates of sowing (YxD) and years with row spacings (YxS) for most of the cases indicated that environments played a greater role on growth and development of summer sesame.

Calculation of net return and CBR (Table 5) are better yardsticks to be used in determining the potential cultural practices.
No doubt, these economic parameters are varying with time period and region specific and depending upon the prevailing rates of inputs and price of the produce. In the present investigation, the highest net return (INR 65,980 ha ${ }^{-1}$ ) and CBR (1:3.30) were obtained when the summer sesame was sown on $15^{\text {th }}$ February with $30 \times 10 \mathrm{~cm}$ spacing. This implies that sesame sowing during summer season in semi-arid agroclimatic environments should be done on $15^{\text {th }}$ February with spacing of $30 \times 10 \mathrm{~cm}$ to obtain maximum profitability. Patel et al. (2010) also reported $15^{\text {th }}$ February as optimum sowing date for realizing higher net return and cost benefit ratio. Whereas, Roy et al. (2009) suggested that row spacing of $30 \mathrm{~cm}$ could be optimum to harvest higher seed yield in sesame.

\section{Conclusion}

It can be concluded from the present study that sowing at $15^{\text {th }}$ February with spacing of $30 \times 10 \mathrm{~cm}$ recorded significantly the highest seed yield (1433 kg ha ${ }^{-1}$ ), branches plant ${ }^{-1}$ (2.03) and 1000-seed weight (3.06) and found to be optimum for cultivation of sesame in summer. Economic parameters also showed the highest cost benefit ratio (1:3.30). Based on these results, it is possible that other cultivars of sesame with the characteristics like G.Til 2 will perform in the same way under semi-arid environments.

\section{References}

Alam Sarkar, M.N., M. Salim, N. Islam, and Rahman, M.M. 2007. Effect of sowing date and time of harvesting on the yield and yield contributing characters of sesame (Sesamum indicum L.) seed, Int. J. Sust. Crop Prod. 2, 31-35.

Caliskan, S., M. Arslan, H. Arioglu, and Isler, N. 2004. Effect of planting method and plant population on growth and yield of 
sesame (Sesamum indicum L.) in a mediterranean type of environment, Asian J. Plant Sci. 3, 610-613.

FAO, 2013. FAOSTAT database. Food and Agriculture Organization of the United Nation, Rome, Italy, Available at http://faostat.fao.org.

Hoshmand, A. R., 2006. Design of experiments for agriculture and natural sciences, $\left(2^{\text {nd }}\right.$ ed), Chapman \& Hall/ CRC, Boca Raton, USA.

Langham, D.R., 2007. Phenology of sesame, In: Issues in New Crops and New Uses(Eds.), J. Janick and A. Whipkey, ASHS Pess, Alexandria,VA., pp.144-182.

Meena, H. M., and Rao, A.S. 2013. Growing degree days requirement of sesame (Sesamum indicum) in relation to growth and phonological development in Western Rajasthan, Curr. Adv. Agric. Sci. $5,107-110$

Monpara, B.A., M.D. Vora, B.M. Chovatiya, and Radadia, B.V. 2008. G. Til 3: A white and bold seeded sesame (Sesamum indicum L.) variety for Saurashtra region of Gujarat, J. Oilseeds Res. 25, 186-187.

Ogbonna, P. E., and Umar-Shaaba, Y. G. 2011. Yield responses of sesame (Sesamium indicum L) to rates of poultry manure application and time of planting in a derived savannah ecology of south eastern Nigeria, Afr. J. Biotech. 10, 14881-87.

Olowe, V.I.O., 2007. Optimum planting date for sesame (Sesamum indicum L.) in the transition zone of south west Nigeria. Agricultura Tropica Et Subtropica. 40, 156-164.

Patel, G.K., I.C. Patel, D.M. Patel, and Patel, G.N. 2010. Production potential of summer sesame varieties in relation to dates of sowing under north Gujarat agroclimatic conditions, J. Oilseeds Res. 27, 74-74.

Patil, B.V., N.T. Shishode, and Dahipale, V.V. 1992. Effect of different sowing date on growth and yield of sesame, J. Maharashtra Agric. Uni. 17, 349-350.

Qiao-yun, L.I., Y.I.N. Jun, L.I.U. Wan-dai, Z.H.O.U. Su-mei, L.I. Lei, N.I.U. Ji-shan, N.I.U. Hong-bin, and Ying, M.A. 2012. Determination of optimum growing degree-days (GDD) range before winter for wheat cultivars with different growth characteristics in North China Plain, J. Integrative Agric. 11405-415.

Rahnama, A., and Bakhshandeh, A. 2006. Determination of optimum row-spacing and plant density for unibranched sesame in Khuzestan Province, J. Agric. Sci. Tech. 8, 25-33.

Ranganatha, A.R.G., 2010. Improved Technology for Maximizing Production of Sesame. (Revised Ed) Project Coordinator, AICRP on Sesame \& Niger, ICAR, JNKVV Campus, Jabalpur, pp.117.

Roy, N., S. M. Abdullah, and Jahan, M. S. 2009. Yield performance of sesame (Sesamum indicum L.) varieties at varying levels of row spacing, Res. J. Agric. Biol. Sci. 5, 823-827.

Singh, M.P., Lallu, and Singh, N. B. 2014. Thermal requirement of Indian mustard (Brassica juncea) at different phonological stages under late sown condition, Indian J. Plant Physiol. 19, 238-243.

\section{How to cite this article:}

Bachubhai A. Monpara and Devshibhai R. Vaghasia. 2016. Optimizing Sowing Time and Row Spacing for Summer Sesame Growing in Semi-arid Environments of India. Int.J.Curr.Res.Aca.Rev. 4(1): 122-131. doi: http://dx.doi.org/10.20546/ijcrar.2016.401.011 